\title{
The decline in mortality from circulatory diseases in Brazil
}

\author{
Cintia Curioni, ${ }^{1}$ Cynthia Braga Cunha, ${ }^{2}$ Renato Peixoto Veras, ${ }^{3}$ \\ and Charles André4
}

Suggested citation Curioni C, Cunha CB, Veras RP, André C. The decline in mortality from circulatory diseases in Brazil Rev Panam Salud Publica. 2009;25(1):9-15.

\begin{abstract}
Objectives. Cardiovascular diseases are the leading cause of death in the world. Although mortality rates have declined gradually in developed countries, the scenario is less clear in developing countries. We describe the trends in cardiovascular mortality in Brazil over 24 years and investigate differences according to groups of diseases, sociopolitical region, gender, and age.

Methods. We retrieved official data on mortality and population estimates to calculate standardized mortality rates in six age strata and in the five political regions from 1980 through 2003. The negative binomial distribution model was used to estimate trends for mortality separately for each gender, age group, and geopolitical region during this period.

Results. Total cardiovascular standardized mortality rates decreased consistently over 24 years, from 287.3 to 161.9 per 100000 inhabitants, with a mean annual decrease of $3.9 \%$. Reductions in cardiovascular standardized mortality rates were detected in all strata and for all groups of diseases, with stroke exhibiting the largest average decline, from 95.2 to 52.6 per 100000 inhabitants (mean $4.0 \%$ per year), followed by coronary disease, from 80.3 to 49.2 per 100000 inhabitants (3.6\% per year); the decrease was especially marked in the most developed regions.

Conclusions. Cardiovascular disease standardized mortality rates consistently decreased in Brazil during the study period. The reduction is apparently related to indices of increasing social development. Despite these encouraging findings, a gradual increase in the deaths from cardiovascular disease is expected in the next decades, and additional efforts in prevention are needed.
\end{abstract}

Key words Cardiovascular diseases, epidemiology, mortality, Brazil

Cardiovascular disease (CVD) has become the leading cause of death in many developing countries and will soon attain this status in several more countries.
The high burden of mortality from CVD in developing countries (estimated at 16.7 million in 2002 and expected to increase to 23.3 million by 2030) (1) is ex-

\footnotetext{
4 Serviço Neurologia, Hospital Universitário Clementino Fraga Filho, Faculdade de Medicina, Universidade Federal do Rio de Janeiro, Rio de Janeiro, Brazil. Send correspondence and reprint requests to: Charles André, Serviço Neurologia, Hospital Universitário Clementino Fraga Filho, Faculdade de Medicina, Universidade Federal do Rio de Janeiro, Rio de Janeiro, Brazil. E-mail: dr.charles. andre@gmail.com
}

plained not only by their large populations but also by the increase in the mean age at death and in the prevalence rates of classic risk factors such as hypertension, smoking, dyslipidemia, diabetes, and obesity (2-6).

An important decline in mortality due to CVD has been detected in developed regions of the world-mainly North America, Western Europe, and Australasia (7-10). It has been suggested that this process could be beginning in Brazil (11, 
12), which seems to be experiencing a phenomenon called epidemiologic transition, in which high (but declining) mortality from health problems characteristic of underdeveloped countries such as infectious diarrhea and gravidpuerperal cycle complications coexist with increasing numbers of fatalities related to chronic degenerative diseases including those of cardiovascular origin.

A number of factors may act in concert to reduce the incidence and death rates from CVD, including stroke and coronary heart disease. These factors may include general factors affecting the whole population or large parts of it-such as a gradual improvement in economic conditions-and more widespread access to drugs used to treat major risk factors such as systemic arterial hypertension and diabetes.

Earlier studies of trends in mortality from CVD in Brazil analyzed data from specific cities or regions or addressed specific diseases (13-15). An extensive analysis of the mortality rates from cardiovascular causes exploring eventual discrepancies between diverse groups of diseases has not been undertaken. Also, possible regional disparities in cardiovascular-related mortality in Brazil have not been previously studied. Inequalities in the distribution of cardiovascularrelated mortality are highly probable, considering the marked discrepancies in general health and socioeconomic conditions throughout the country. We have shown that between 1980-1982 and 2000-2002 stroke mortality rates in Brazil declined more steeply in the richest regions (16). We now present the evolution of mortality rates from the main groups of CVDs in Brazil from 1980 through 2003, exploring possible differences according to age and gender and among diverse geopolitical regions exhibiting marked socioeconomic disparities.

\section{MATERIALS AND METHODS}

The number of deaths from cardiovascular causes was obtained from the Brazilian Mortality Information System made available by the National Health Ministry (17). Data were obtained for all cardiovascular deaths and for four large groups of diseases: coronary heart disease, stroke, complications of hypertension (essentially cardiac and renal disease), and other causes. For the years 1980 through 1995, causes of death were classified according to the ICD-9 code system: coronary heart disease (410414), stroke (430-438), complications of hypertension (401-405), and other causes (390-398, 415-429, 440-459). From 1996 on, the ICD-10 system was used: coronary heart disease (120-125), stroke (160-169), complications of hypertension (110-113), and other causes (100-109, 126-151, 170-199).

The mortality rate estimates, expressed as the number of deaths per 100000 inhabitants, were calculated for the population estimates derived from the Brazilian censuses held in 1980, 1991, 1996, and 2000 (Brazilian Institute of Geography and Statistics) and also made available by the National Health Ministry (17). The intercensus populations (1981-1990, 1992-1995, 1997-1999, 20012003) used in these calculations were estimated from the Lagrange interpolation, classified according to region, gender, and age strata. The age distribution is presented according to the Pan American Health Organization system.

All rates were standardized by age through the direct method, with the total Brazilian population from 2000 as the standard-derived from the Brazilian census held in 2000 by the Brazilian Institute of Geography and Statistics and also made available by the National Health Ministry (17). In summary, the procedure consisted of a number of sequential steps (18). Specific mortality rates for each period were calculated for the six prespecified age groups; these rates were then applied to the standard population, resulting in an "expected mortality" for each age group. The ratio between the sum of the expected mortality of all age groups and the total population in the same period resulted in the age-standardized mortality rate (SMR).

We explored the evolution of cardiovascular mortality rates, stratifying them by gender, age group, and region. There are five geopolitical regions in Brazil, two of which (Southeast and South regions) have a distinctly higher gross internal product and mean income per capita. Correction for undefined causes of death was routinely made, as a large, although declining, proportion of death certificates in Brazil still carry this label (e.g., $21.5 \%$ of deaths in 1980 versus $15.1 \%$ in 1999) (19).

Trends for mortality from CVD—total and related to the four prespecified groups of diseases-during the 1980-
2003 period in Brazil and separately for each gender, age group (six categories), and geopolitical region (five categories) were analyzed with the negative binomial regression model. This model was used because of overdispersion found in the analyzed data (20).

The model is represented as follows:

$$
\log (\text { event rate })=\alpha+\beta \times \text { year }+\varepsilon
$$

where $\alpha$ indicates the intercept, $\beta$ is an angular coefficient, and $\varepsilon$ is random error.

Models were constructed for each stratum of the variables considered-for example, a model for mortality in females, a model for mortality in the 20- to 34-year age group, and so forth.

We obtained the average annual percent change for disease rates with the following formula: $100[\exp (\beta)-1]$.

For all statistical analyses, we considered a $P$ value $<0.05$ to be statistically significant. All analyses were performed with the statistical software package SAS for Windows 9 (21).

\section{RESULTS}

The number of deaths from CVD in Brazil stratified by gender in 1980 and 2003 is presented in Table 1 . The total number of deaths attributable to CVD in Brazil increased steadily during the period studied. The mean annual number of deaths increased $45 \%$ between 1980 and 2003; a similar trend was evident for all four groups of diseases. This increase mainly reflects the progressive aging and growth of the Brazilian population.

Nevertheless, the SMR consistently decreased in Brazil between 1980 and 2003 for all groups of diseases (Table 2 and Figure 1): total cardiovascular mortality rates exhibited a mean annual reduction of $3.9 \%$ per 100000 inhabitants. Stroke exhibited the highest mortality rates among CVD but also the largest average annual decline-4.0\% per 100000 inhabitants per year; rates related to coronary disease exhibited an average reduction of $3.6 \%$ per 100000 inhabitants. During the same period, all-cause mortality rates in Brazil also declined markedly, from 631.41 to 541.73 per 100000 inhabitants (a mean annual reduction of $3.9 \%$ ).

For both genders, there was a statistically significant declining trend for death rates from all CVD and from the four subgroups of diseases $(P<0.0001$ 


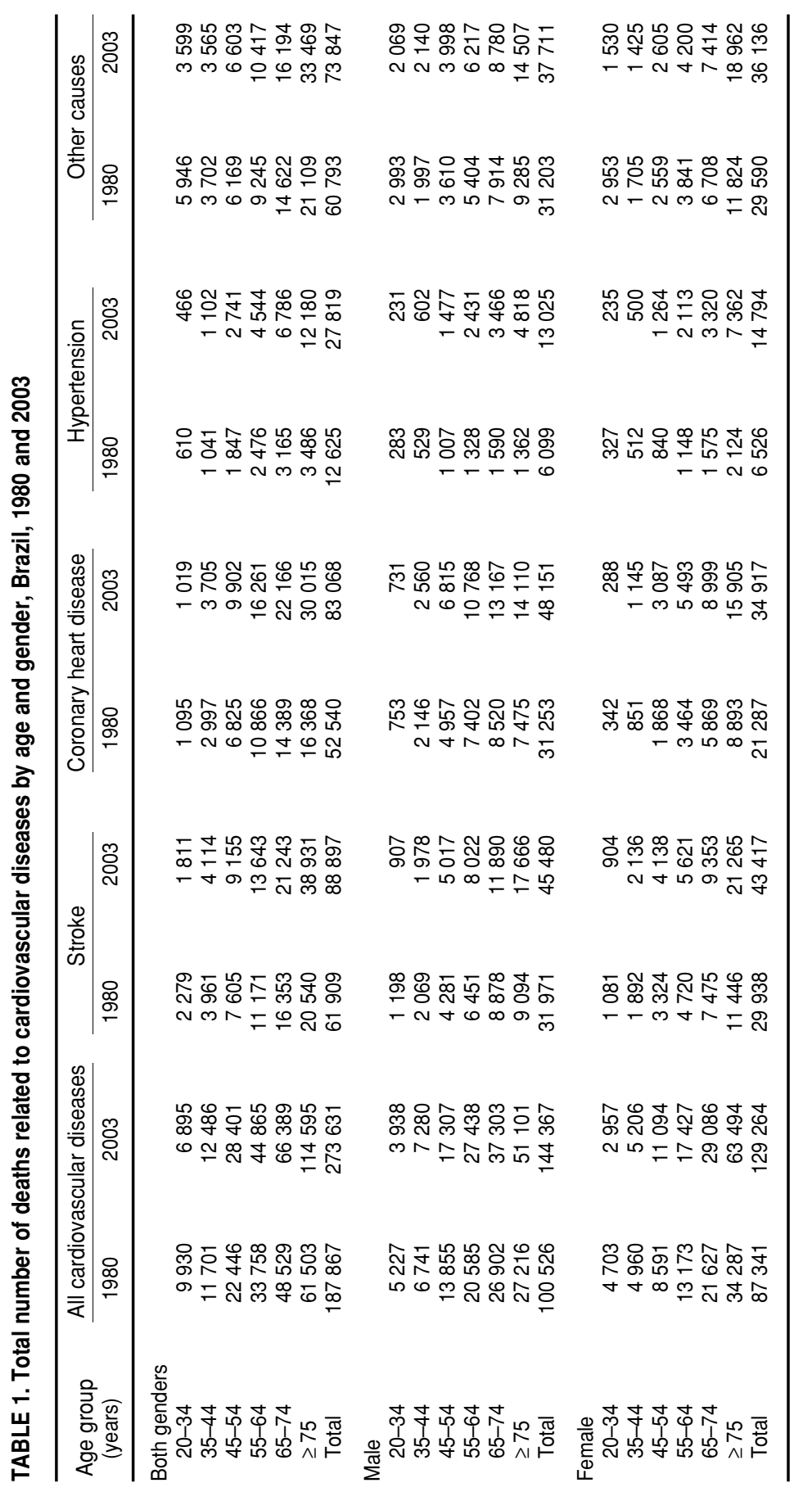

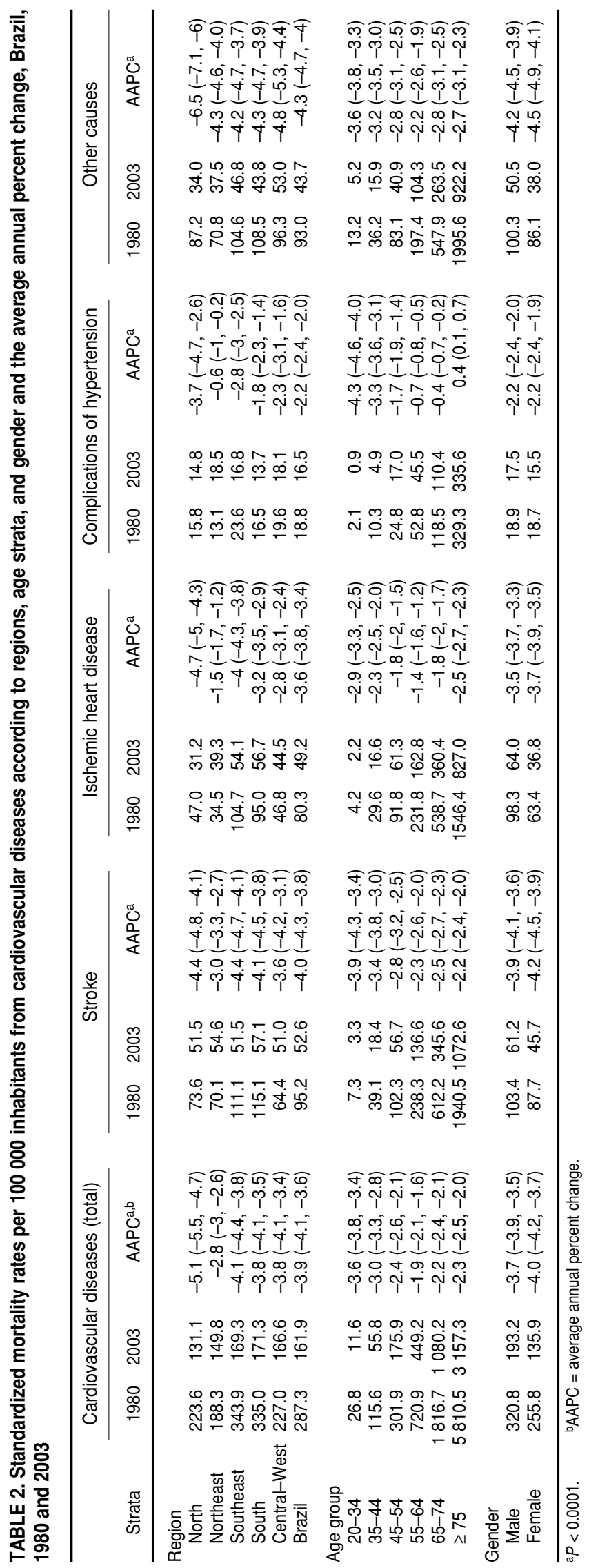


FIGURE 1. Evolution of standardized mortality rates attributable to cardiovascular diseases, Brazil, between 1980 and 2003

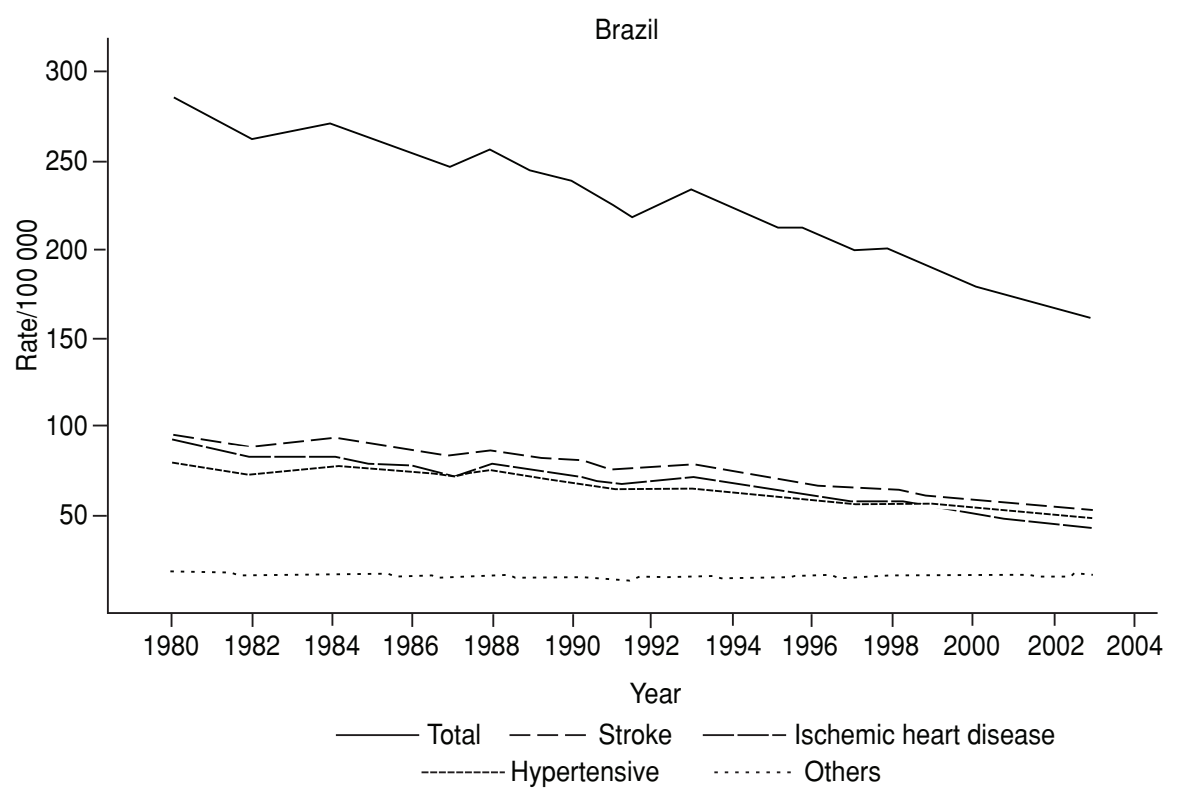

FIGURE 2. Evolution of standardized mortality rates attributable to cardiovascular diseases according to gender, Brazil, between 1980 and 2003

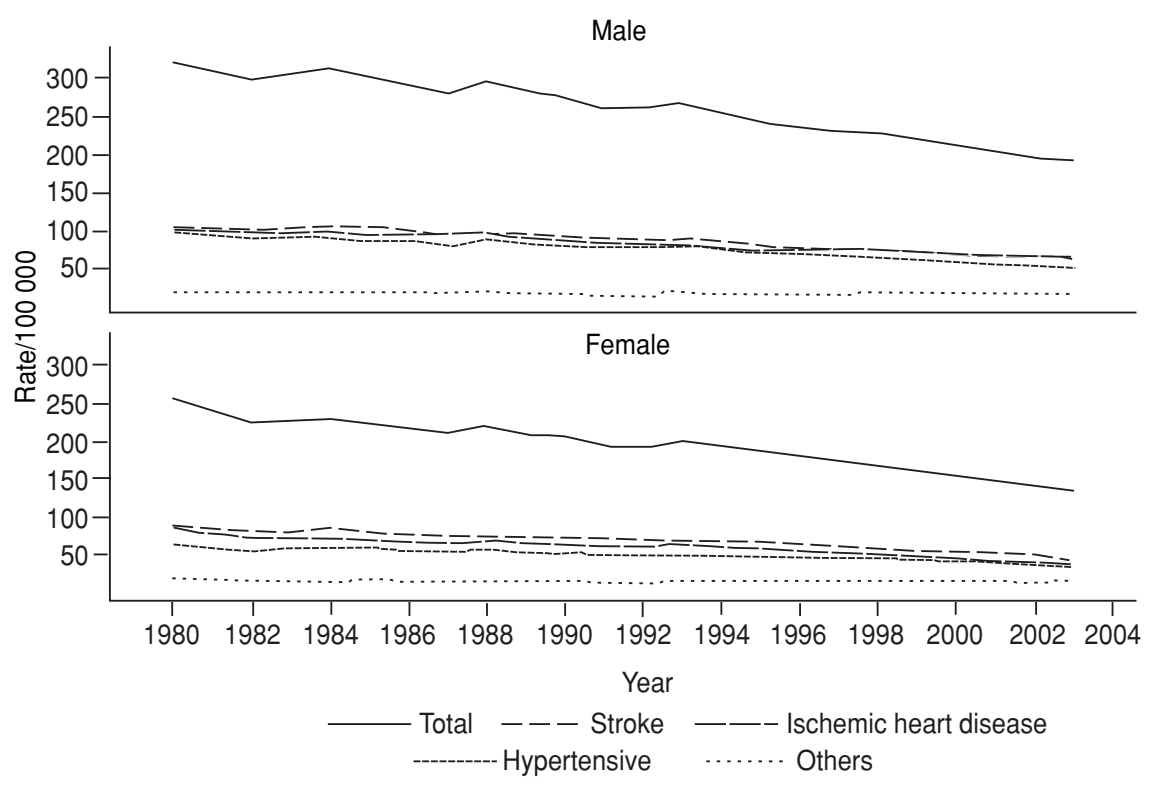

for all). The average annual percent decline was similar for men and women in all categories of diseases (Table 2). Stroke was the main cause of death in women in 1980 and again in 2003. Since 1999, ischemic heart disease has surpassed stroke as the leading cause of decline over the last 24 years $(P<0.0001$ for all findings). Mortality related to hypertensive complications in the oldest population group ( $\geq 75$ years) constituted an isolated exception, with rates increasing slightly (mean $0.4 \%$ per year) over the period studied.

A reduction in mortality rates occurred in all geopolitical regions (Table 2 and Figure 1). The North region exhibited more marked reductions during the study period; this finding must be interpreted with caution because a parallel increase in migratory inflow from other Brazilian regions occurred between 1980 and 1991, resulting in a much higher than average demographic expansion in that region (22). Excluding the North region, the wealthiest regions (South and Southeast) exhibited higher initial mortality rates from CVD and also more marked reductions over time than other, less well-developed regions. The trends move in the same general direction for stroke and ischemic heart disease.

\section{DISCUSSION}

SMR from CVD consistently decreased in Brazil over a period of 24 years. A parallel reduction in all-cause mortality rates has also been demonstrated. In the early 1980s, CVD constituted the primary cause of death in Brazil, followed by external causes, infectious diseases, cancer, and respiratory diseases. In 2003, the scenario was similar, with a relative increase in mortality from cancer, now second to CVD, and a decline in mortality from infectious diseases, now in the fifth position. Among these five groups of diseases, only CVD and infectious diseases presented decreasing mortality rates during the study period. The process of epidemiologic transition is still under way in Brazil, where mortality from infectious diseases and undernutrition has declined steadily over the last 70 years (most markedly between 1930 and 1985), and mortality due to CVD increased until the early 1970s; after a period of apparent stability between 1970 and 1985, it now exhibits a gradual decline similar to what happened in developed countries in previous decades (23). This trend is somewhat different from what happened in the United States of America and Western Europe, for instance, where marked declines in mortality due to CVD were detected between 1970 and $2000(24,25)$. 
On the other hand, stability or even an increase in CVD mortality was evident in Eastern Europe and in underdeveloped countries during the 1980s and 1990s $(24,25)$.

A striking finding of this study is the homogeneous decline in CVD mortality from all groups of causes in both genders and in all age strata (an isolated exception is deaths related to hypertension in the oldest stratum). This finding strongly suggests the interplay of factors that influence the incidence of CVD in the whole population such as a reduction in mean salt consumption and blood pressure levels. The main classes of antihypertensive drugs ( $\beta$-blockers, calcium channel blockers, angiotensinconverting enzyme inhibitors, and diuretics) can now be obtained at no expense through the public health system (26). The importance of blood pressure control as a core determinant of the global reduction in CVD mortality is also suggested by the steeper decline in stroke mortality detected and resulting in coronary artery disease becoming the leading cause of death in men from 1999 on. In clinical trials, the reduction in the incidence of stroke has been greater than the reduction in the incidence of myocardial infarction-35\% to $40 \%$ versus $20 \%$ to $25 \%$ (27). Another factor with a potentially large impact should also be mentioned. The National Program of Smoking Control resulted in a $32 \%$ decrease in per capita annual cigarette consumption between 1989 and 2002 as well as a reduction in the prevalence of current smoking (28).

A reduction in hospital mortality over time is also probably a factor leading to the detected reduction in CVD mortality. The availability of hospital beds in Brazil decreased during the study period, from 3.7 per 1000 individuals in 1980 to 3.1 per 1000 in 2001 (29). It should be mentioned that during this period intensive care units and coronary care units became widely available (30). The appearance and increasing availability of procedures potentially resulting in greater diagnostic accuracy or therapeutic benefit such as computerized tomography, echocardiography, endovascular interventions, and renal dialysis should also be mentioned as contributing factors (31).

The reduction in CVD mortality during the period studied appears to be related to indices of increasing social development. Coronary heart disease is now (since 1999) the leading cause of death in the richest region of the country (Southeast). We found an inverse and strong correlation between the human development index (HDI), which increases in association with improved economic and social indicators (life expectancy, education attainment, and income per capita) (32), and CVD mortality between 1980 and 2000 (data available from the authors): Spearman correlation coefficient $=-1.0 ; P<0.001$. The importance of socioeconomic determinants is highlighted by the fact that, although the reduction in CVD mortality rates occurred in all geopolitical regions, it was more marked in the South and Southeast regions-responsible for $75.4 \%$ of the crude internal product and with a higher HDI (33) - and less so in other regions, which exhibit medium (but also increasing) HDI and can be seen as nonestablished market economy regions.

The interregional differences probably reflect the variable impact of a number of factors including lifestyle differences (physical activity, smoking, dietary habits), thoroughness of detection and control of classic risk factors such as hypertension and diabetes, and differences in hospital care. The two wealthiest regions, for example, concentrate three-quarters of magnetic resonance imaging and computerized tomography machines, with additional intrinsic access inequalities (equipment heavily concentrated in private facilities that assist only $17.4 \%$ of the population). The corresponding figures for health facilities with emergency departments, intensive care beds, and coronary care units are $65 \%, 71 \%$, and $88 \%$, respectively (33).

Disparities in CVD mortality according to socioeconomic factors have been observed in other countries. The odds of coronary heart disease in both genders are more than two times greater in lowincome groups (34). In the United States of America, CVD mortality appears to vary according to racial origin (probably reflecting different lifestyle and dietary risk factors) as well as to social disparities (35). A recent Scottish study indicates that area-based indicators of poverty and individual social class influence the prevalence of common risk factors and morbidity and mortality from CVD (36).

Despite the encouraging finding of a steadily declining cardiovascular SMR, the total number of deaths from CVD in
Brazil progressively increased in recent decades. This fact could reflect total population growth and also a progressive increase in mean age of the population, which will continue in the future. Mean life expectancy increased from 62.6 years for people born in 1980 to 71.7 years for those born in 2004 (37). The projected life expectancy for those born in 2020 is 76.1 years. Additional factors in the future may lead to a relative increase in the number of CVD deaths such as the observed increase in the prevalence of diabetes and obesity $(28,38)$. A national program to guarantee free access to treatment for hypertension and diabetes was launched in 2002 and was conceived to revert the present picture of a very low degree of control of hypertension in large cities (26). Developing countries face problems of prohibitive costs of care and therefore a huge emphasis should be placed on primary preventive strategies to effectively deliver treatment for hypertension and other cardiovascular risk factors (39).

A potential limitation of this study should be mentioned. Death certificates are the only data source available to assess population trends in CVD mortality. However, the reliance on death certificates may introduce bias, as it could be influenced by the quality of data recording, a worldwide problem (40). In Brazil, the quality of mortality data collection is traditionally worse in regions with lower socioeconomic indices (19). However, a gradual improvement in data recording is being noted (19). In the future, a relative increase in the proportion of deaths attributable to CVD could be reported in poorer regions, because most of the so-called deaths of undetermined cause are actually due to cardiovascular conditions.

In conclusion, over the past 24 years, CVD mortality in Brazil decreased steadily in women and men in all age strata, but the magnitude of the decline varied according to regional socioeconomic differences. Furthermore, with the progressive increase in the total number of annual deaths from CVD expected in the coming decades, additional prevention efforts should be encouraged. Considering the observed association between socioeconomic conditions and CVD mortality, broad interventions may be more successful if planned according to social inequality and cultural differences. 


\section{REFERENCES}

1. Mathers CD, Loncar D. Projections of global mortality and burden of disease from 2002 to 2030. PLoS Med. 2006;3(11):e442.

2. Erdine S, Aran SN. Current status of hypertension control around the world. Clin Exp Hypertens. 2004;26(7-8):731-8.

3. Fagerstrom K. The epidemiology of smoking: health consequences and benefits of cessation. Drugs. 2002;62(Suppl 2):S1-9.

4. World Health Organization. Obesity: preventing and managing the global epidemic. Technical Report Series 894, Geneva: WHO; 2000.

5. Liu L, Ikeda K, Chen M, Yin W, Mizushima S, Miki T, et al. Obesity, emerging risk in China: trend of increasing prevalence of obesity and its association with hypertension and hypercholesterolaemia among the Chinese. Clin Exp Pharmacol Physiol. 2004;31(Suppl 2):S8-10.

6. de Sereday MS, Gonzalez C, Giorgini D, De Loredo L, Braguinsky J, Cobenas C, et al. Prevalence of diabetes, obesity, hypertension and hyperlipidemia in the central area of $\mathrm{Ar}-$ gentina. Diabetes Metab. 2004;30(4):335-9.

7. Ergin A, Muntner P, Sherwin R, He J. Secular trends in cardiovascular disease mortality, incidence, and case fatality rates in adults in the United States. Am J Med. 2004;117(4): 219-27.

8. Levi F, Lucchini F, Negri E, La Vecchia C. Trends in mortality from cardiovascular and cerebrovascular accidents in Europe and other areas of the world. Heart. 2002;88(2): $119-24$.

9. Reid CM, Nelson MR. Cardiovascular risk factor control in Australia: current status and implications for the future. Aust Fam Physician. 2005;34(6):405-6.

10. Kesteloot H, Sans S, Kromhout D. Dynamics of cardiovascular and all-cause mortality in Western and Eastern Europe between 1970 and 2000. Eur Heart J. 2006;27(1):107-13.

11. Oliveira GM, Silva NA, Klein CH. Balanced cardiovascular disease mortality from 1980 to 1999-Brazil. Arq Bras Cardiol. 2005;85(5): 305-13.

12. Mansur AP, Favarato D, Souza MF, Avakian SD, Aldrighi JM, Cesar LA, et al. Trends in death from circulatory diseases in Brazil between 1979 and 1996. Arq Bras Cardiol. 2001; 76(6):497-510.

13. Lolio CA, Souza JMP, Laurenti R. Decline in cardiovascular disease mortality in the city of S. Paulo, Brazil, 1970 to 1983. Rev Saúde Pública. 1986;20:454-64

14. Lolio CA, Lotufo PA, Lira AC, Zanetta DM, Massad E. Mortality trends due to myocardial ischemia in capital cities of the metropolitan areas of Brazil, 1979-89. Arq Bras Cardiol. 1995;64(3):195-9.

15. Lotufo PA. Premature mortality from heart diseases in Brazil. A comparison with other countries. Arq Bras Cardiol. 1998;70(5): 321-5.

16. André C, Curioni CC, Braga da Cunha C, Veras R. Progressive decline in stroke mortality in Brazil from 1980 to 1982, 1990 to
1992, and 2000 to 2002. Stroke. 2006;37(11): 2784-9.

17. Ministério da Saúde/Secretária de Vigilância em Saúde/Departamento de Análise de Situação de Saúde. Available from: http://tabnet. datasus.gov.br. Accessed 14 Nov 2006.

18. Rothman KJ. Modern epidemiology. Boston: Little Brown \& Co.; 1986. Pp. 41-50.

19. Mello Jorge MHP, Gotlieb SLD, Laurenti R. The National Mortality Information System: problems and proposals for solving them, I: deaths by natural causes. Rev Bras Epidemiol. 2002;5(2):197-211.

20. Kleinbaum DG, Kupper LL, Muller KE, Nizam A. Applied regression analysis and other multivariable methods. 2nd ed. Pacific Grove, California: Brooks/Cole Publishing Co; 1998. Pp. 687-710.

21. Stokes ME, Davis CS, Koch GG. Categorical data analysis using the SAS system. 2nd ed. Cary, North Carolina: SAS Institute, Inc; 2000. Pp. 347-62.

22. Moreira MM. Região Norte: evolução populacional recente. In: de SANTOS, Taís de Freitas. Dinâmica populacional das regiões Norte e Nordeste: questões atuais e emergentes. Recife: FJN, Editora Massangana, 2000. Pp. $45-81$.

23. Prata PR. The epidemiologic transition in Brazil. Cad Saúde Publ. 1992;8(2):168-75.

24. Rodriguez T, Malvezzi M, Chatenoud L, Bosetti C, Levi F, Negri E, et al. Trends in mortality from coronary heart and cerebrovascular diseases in the Americas: 1970-2000. Heart. 2006;92(4):453-60.

25. Kesteloot H, Sans S, Kromhout D. Dynamics of cardiovascular and all-cause mortality in Western and Eastern Europe between 1970 and 2000. Eur Heart J. 2006;27(1):107-13.

26. Ramos ACMF, Seixas TC, Rocha CRM, Avila RT. O programa de controle da hipertensão arterial no sistema público de saúde do $\mathrm{Mu}$ nicípio do Rio de Janeiro. Rev SOCERJ. 2003;16(2):142-6.

27. Chobanian AV, Bakris GL, Black HR, Cushman WC, Green LA, Izzo JL, et al. The seventh report of the Joint National Committee on Prevention, Detection, Evaluation, and Treatment of High Blood Pressure: the JNC 7 report. JAMA. 2003;289(19):2560-72.

28. Brasil. Ministério da Saúde. Secretaria de Vigilância em Saúde. Secretaria de Atenção à Saúde. Instituto Nacional de Câncer. Coordenação de Prevenção e Vigilância. Inquérito domiciliar sobre comportamentos de risco e morbidade referida de doenças e agravos não transmissíveis: Brasil, 15 capitais e Distrito Federal, 2002-2003. Rio de Janeiro: INCA, 2004. Available from: http://portal.saude. gov.br/saude. Accessed 27 April 2007.

29. Organization Panamericana de la Salud, Division de Salud y Desarollo Humano, Programa de Analisis de la Situation de Salud. Situation de salud en las Americas. Indicadores basicos, 1998. Washington, DC: PAHO; 1998. 16A. Organization Panameri- cana de la Salud, Analisis de Salud y Sistemas de Information. Atlas de indicadores basicos, 2001. Iniciativa Regional de Datos Basicos en Salud. Washington, DC, 2002.

30. Bassan R, Souza P, Bassan F. Inquérito de unidades de dor torácica-2002. Rev SOCERJ. 2004;17(2):140-7

31. Nunes A, Santos JRS, Barata RB, Vianna SM. Medindo as desigualdades em saúde no Brasil: uma proposta de monitoramento. Brasília: Organização Pan-Americana da Saúde, Instituto de Pesquisa Econômica Aplicada, 2001.

32. United Nations Development Programme. Human development report 2006 beyond scarcity: power, poverty and the global water crisis. Available from: http://hdrstats.undp. org/countries/display_cf_xls_ds.cfm?cty_id $=$ BRA. Accessed 24 May 2007.

33. IBGE, Diretoria de Pesquisas, Coordenação de População e Indicadores Sociais, Pesquisa de Assistência Médico-Sanitária 2002. Available from: http://www.ibge.gov.br/home/ estatistica/populacao/condicaodevida/ indicadoresminimos/sinteseindicsociais2003/ indic_sociais2003.pdf. Accessed 25 April 2007.

34. Kivimaki M, Lawlor DA, Davey Smith G, Kouvonen A, Virtanen M, Elovainio M, et al. Socioeconomic position, co-occurrence of behavior-related risk factors, and coronary heart disease: the Finnish public sector study. Am J Public Health. 2007;97(5):874-9.

35. Cooper RS. Social inequality, ethnicity and cardiovascular disease. Int J Epidemiol. 2001;30(Suppl 1):S48-52.

36. Smith GD, Hart C, Watt G, Hole D, Hawthorne V. Individual social class, area-based deprivation, cardiovascular disease risk factors, and mortality: the Renfrew and Paisley study. J Epidemiol Community Health. 1998; 52(6):399-405.

37. IBGE/Diretoria de Pesquisas. Coordenação de População e Indicadores Sociais. Gerência de Estudos e Análises da Dinâmica Demográfica. Projeção da população do Brasil por sexo e idade para o período 1980-2050. Revisão 2004. Available from: http://www.ibge.gov. br. Accessed 20 April 2007.

38. Sartorelli DS, Franco LJ. Trends in diabetes mellitus in Brazil: the role of the nutritional transition. Cad Saúde Publ. 2003;19(Suppl 1):S29-33.

39. Gyarfas I. Lessons from worldwide experience with hypertension control. J Hum Hypertens. 1996;10(Suppl 1):S21-25.

40. Lakkireddy DR, Basarakodu KR, Vacek JL, Kondur AK, Ramachandruni SK, Esterbrooks DJ, et al. Improving death certificate completion: a trial of two training interventions. J Gen Intern Med. 2007;22(4):544-8.

Manuscript received on 5 September 2007. Revised version accepted for publication on 2 April 2008 
RESUMEN Objetivos. Las enfermedades cardiovasculares constituyen la primera causa de muerte en el mundo. Aunque las tasas de mortalidad han disminuido gradualmente en los países desarrollados, el escenario es menos claro en los países en desarrollo. Se

\section{Disminución en la mortalidad por enfermedades cardiovasculares en Brasil}

describen las tendencias de la mortalidad por enfermedades cardiovasculares en Brasil durante 24 años y se analizan las diferencias según el grupo de enfermedades, la región, el sexo y la edad.

Métodos. Se tomaron los datos oficiales de mortalidad y los estimados de población para calcular las tasas de mortalidad estandarizadas en seis grupos de edad y cinco regiones sociopolíticas entre 1980 y 2003. Se empleó el modelo de distribución binomial negativa para estimar las tendencias de la mortalidad por sexo, grupo de edad y región geopolítica en ese período.

Resultados. Las tasas de mortalidad estandarizadas totales por enfermedades cardiovasculares disminuyeron sistemáticamente en los 24 años, de 287,3 a 161,9 por 100000 habitantes, con un decrecimiento anual promedio de 3,9\%. Se encontraron decrecimientos en las tasas de mortalidad estandarizadas en todos los grupos de edad y de enfermedades. Los accidentes cerebrovasculares presentaron la mayor reducción (de 95,2 a 52,6 por 100000 habitantes; media anual: 4,0\%), seguidos de la enfermedad coronaria (de 80,3 a 49,2 por 100000 habitantes; media anual: 3,6\%). La disminución fue más acentuada en las regiones de mayor desarrollo.

Conclusiones. Las tasas de mortalidad estandarizadas por enfermedades cardiovasculares disminuyeron sistemáticamente en Brasil en el período estudiado. Aparentemente, esta reducción está relacionada con los índices de aumento en el desarrollo social. A pesar de estos alentadores resultados, se espera un aumento gradual en las muertes por enfermedades cardiovasculares en las próximas décadas, por lo que se requiere un esfuerzo preventivo adicional.

Palabras clave Enfermedades cardiovasculares, epidemiología, mortalidad, Brasil. 